\title{
Transposition
}

Musique et Sciences Sociales

$3 \mid 2013$

Musique et théorie queer

\section{Classical Concert Music and Queer Listening}

\section{Fred Everett Maus}

\section{OpenEdition}

\section{Journals}

Electronic version

URL: http://journals.openedition.org/transposition/148

DOI: 10.4000/transposition. 148

ISSN: $2110-6134$

\section{Publisher}

CRAL - Centre de recherche sur les arts et le langage

\section{Electronic reference}

Fred Everett Maus, «Classical Concert Music and Queer Listening », Transposition [Online], 3 | 2013, Online since 01 March 2013, connection on 20 April 2019. URL : http://journals.openedition.org/ transposition/148; DOI : 10.4000/transposition.148

This text was automatically generated on 20 April 2019.

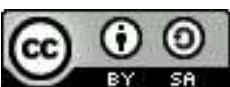

La revue Transposition est mise à disposition selon les termes de la Licence Creative Commons Attribution - Partage dans les Mêmes Conditions 4.0 International. 


\title{
Classical Concert Music and Queer Listening
}

\author{
Fred Everett Maus
}

\section{AUTHOR'S NOTE}

I wrote the first version of this paper for a conference, "The Art of Listening", which took place July 12-14, 2012 at Radialsystem in Berlin. I am grateful to Christian Thorau and Hansjakob Ziemer for inviting me to participate. The conference gathered many scholars who have shaped recent discussions of listening, especially in relation to concerts of classical music. Among the eminent presenters were Katherine Ellis, Lydia Goehr, James Johnson, Richard Leppert, Jonathan Sterne, and William Weber; I have listed some of their splendid, field-defining publications in the bibliography. I used my presentation as an opportunity to bring together a description of normative concert listening and the reflections on musical eroticism that appeared in U.S. musicology from the late 1980s on; these two styles of discourse about music have rarely interacted. ${ }^{1}$

1 A concert is about to begin, and I enter the space of the performance. I am imagining that this is a concert of classical instrumental music, perhaps a solo concert, or a performance by a chamber ensemble, or an orchestra. If the concert hall is small, it will hold a few hundred people; a larger hall might have close to 3000 seats. I might be with someone I know, or I might be alone. If the concert is in the small city where I live, the audience will include many people whom I know; if I am visiting a larger city, I might or might not recognize anyone.

2 For a few minutes, I take note of the people around me, perhaps interacting warmly with people I know or politely with strangers, as we all find our seats. Before the music begins, I might look around the hall, noticing whether there are empty seats, what kinds of people have chosen to come, what people are wearing; or I might be absorbed in conversation with a companion. I might leaf through the program. 
Once the concert begins, I know exactly how to behave; I know it so well that I don't even think of it as a way of behaving, more as a natural response to the presence of the music. Like others who follow the present-day norms of classical concert behavior, I will seem to ignore the people around me. Possibly I will focus visually on the concert stage, looking straight ahead like many other members of the audience. Or I might look up, or down, not looking at anything in particular but just resting my eyes. In whatever way I use my eyes, I know that listening is much more central than looking. My attention should rest in the sounds I hear; perhaps my sonic perceptions will be augmented or articulated in some way by what I see the performers doing, but I need not watch them if I do not wish to do so.

There is discontinuity in my transition from the embodied social creature that entered the concert hall to something else, an auditory creature perhaps, somehow living in a world of sounds. Starting now, according to a widely shared understanding of the classical concert, my experience is more purely my own. As an individual, I will have an encounter with the music, primarily through experience of musical sound. And later, no matter how talkative I may become, discussing the concert during the intermission or afterward, my conversation partners and I will understand our experiences to be, in important respects, ineffable.

5 Musical experiences at the concert are individual, in that everyone must have her own experience; and we also expect these experiences to be individually variable. Sitting in rows, still and quiet, facing the same direction, outwardly uniform in posture and behavior, we may nonetheless have very different thoughts and feelings. After listening, our conversations may compare experiences, recognizing commonalities, exploring and perhaps enjoying differences, but we don't assume that we will fully understand the experiences of others. While recognizing the diversity of experiences, we also assume that the shared experience of a musical performance may create a sense of intimacy among audience members, perhaps between two people spending the evening together, perhaps among a larger group at the performance, people who know each other or people who are just there at the same time. We also assume that some people at the concert will be distracted, inattentive, or unresponsive; we think of them as missing something by not taking pleasure in sustained attention to the music.

6 Above all, most people at the concert probably expect their musical experience to be special; it might be intense, compelling, important, exalting, exquisite, even transformative. There is little in the customary relaxed, friendly social comportment of concert-goers, before and after the listening experience, nor in our visible attitude of calm attention while listening, that reflects these more remarkable qualities.

7 I've been articulating conventional attitudes about conventional classical concert experiences, attitudes I learned growing up in the United States in the late $20^{\text {th }}$ century. The practices that I am describing are widespread, but historically specific. We know that other audiences have related differently to similar music, not to mention people in the presence of very different music. Bear with me: it's this disciplined modern classical music experience that I am considering. I have no interest in universal or trans-historical claims; and anyway, apart from hard-won historical or cross-cultural information, it's obvious to all that the formal classical concert is only one among many present-day contexts for relating to music. Alternatives abound, right outside the concert hall discos, Gospel church services, iPods, car radios, and so on. 
The classical concert, as I have described it, depends upon and dramatizes several binary oppositions: collective audience versus individual experience, public social event versus private and ineffable experience, bodily stillness versus lively activation of the mind and spirit. The concert event repeats and reinforces these oppositions that also recur throughout other parts of our culture. In accord with these conceptualizations, the concert audience comes together, paradoxically, to share an experience of separation into multiple, insular subjectivities.

Others ways of listening to classical music - in a car, in a home, through headphones at the gym - may seem very different. But, in my experience, classical music usually carries with it, into these physically private settings, the idea of a collective audience. No doubt, this results partly from the near-disappearance of domestic music making.

In a classical recording, I don't usually hear abstract sound patterns; I hear musicians doing something. And even if I know that the recording comes from a studio, the idea of possible performance for an audience remains part of my experience. But also, however private one's actual technologically-mediated listening may be, classical music places the listener in relation to an imagined collectivity of other listeners - not just an imagined audience in an imagined performance space, but even more, the scattered community of actual performers and listeners in various times and places who have cared about, for instance, the music of Mozart or Ravel, or whatever one is hearing.

11 If audience members and other classical music listeners are thought to have private, individual experiences, what is the content or nature of those experiences? There are many possible answers, roughly coextensive with the actual and potential literatures of classical music criticism and analysis! I already noted that, according to common ideas, experiences of classical music are individual, variable, and, to some degree, ineffable. In that case, one should not expect to offer a uniform or fully explicit account of the content of listeners' experiences. (Nor need one rush to adjudicate among heterogeneous styles of music criticism and musical analysis.) Still, there are patterns, recurring types of experience across different musical events and different listeners. In the following comments, I focus on a range of recurring patterns that is particularly salient to my own experiences and those of many other people: musical experiences often seem to "humanize" and "eroticize" musical sound.

12 Classical music listeners often say that they "love" specific composers, compositions, performers, performances, moments in pieces, and so on. Less ardently, they may express fondness, liking, respect, or admiration. Listeners also say that they understand specific composers, performers, compositions, moments in compositions, and so on (or sometimes that they do not understand them). Such claims of understanding do not imply that we can say in words what we have understood; it is a different kind of understanding, more like understanding a friend than understanding a linguistic statement. Affectively and cognitively, listeners often seem to relate to music as though they are interacting with other human beings - not only the actual composers or performers, but also fictional or fantasized human agencies, perhaps incompletely or indeterminately imagined.

13 Admirers of classical music have strong personal responses that range among various emotions and sensations. Classical music can give gentle or intense pleasure; it also creates excitement, tension, anxiety, chills, repose, meditative stillness, and many other vivid experiential qualities. The persistent, engaging rhythmic repetition of much classical music can be sensual and entrancing. When musical experiences are intense, 
people sometimes say that they have been thrilled, ravished, or overwhelmed. Listeners vary in their susceptibility to emotional and sensational responses, and different music will lend itself to different kinds and degrees of feelings. But, at least for some listeners, the experience of classical music can be, in some sense, erotic in its sensual and emotional qualities; or perhaps one should say that musical experience sometimes has close affinities with erotic experience.

In Anglophone musicology of the late 1980s and early 1990s, scholars began to write frequently about music in relation to gender and sexuality. Some of the most provocative texts emphasized erotic or sexual qualities of music. In particular, I have long been grateful to Susan McClary's book Feminine Endings, published in 1991, and Suzanne Cusick's essay "On a Lesbian Relationship with Music", memorably presented at a conference in 1991 and published in 1994, for opening fascinating lines of thought about music and sexuality. ${ }^{2}$ I believe such work makes important contributions to understanding the intensity of musical experience.

McClary's classic book approaches gender and sexuality in several different ways. She makes use of the common harmonic narrative in which polarized keys resolve in favor of a single tonic; she argues that the keys often associate with gendered musical styles, and that the narrative typically affirms masculinity. McClary also describes different temporal patterns in music, emphasizing a contrast between goal-oriented temporalities that drive toward climaxes or cadential closure, and more present-oriented temporalities that seem to sustain feeling rather than pressing toward future goals.

McClary's psychology of musical experience emphasizes identification. Listening attentively to music, one feels its qualities as though they are one's own. Thus, hearing various temporal patterns - arousal and climax, or pleasure sustained through repetition, or the narrative resolution of a conflict of tonal centers - it is as though one feels what the music feels, enjoys and desires what the music enjoys and desires. If music structures time in ways that resemble gendered narratives, or patterns of sexual pleasure, listeners may welcome their identification with these structures, or may find that the music that solicits their identification is foreign to their own sensibilities.

McClary associates goal-directed motion and narratives of tonal unity with influential constructions of men and masculinity, sustained pleasure and harmonic openness with complementary constructions of women and femininity. Through such associations, in her treatment, issues of musical identification become political issues of gender and sexuality.

eminine Endings draws on ideas associated with the 1970 s and 80 s that placed sexual experience at the center of feminist politics, and emphasized that men and women may come to sexual encounters with different needs and expectations. In some such treatments, conventional heterosexual intercourse is the defining practice that marks men and women as unequal in power.

The placement of sexuality at the center of gender difference and gender politics took an extreme form in the work of the influential feminist activists Andrea Dworkin and Catherine MacKinnon. ${ }^{3}$ According to Dworkin and MacKinnon, men routinely use women sexually to affirm their own masculine power, desiring but despising the women they penetrate. The solution to this abusive pattern would be, centrally, the development of other sexual practices. Men might learn to practice egalitarian, non-penetrative sex; more likely, women might have egalitarian non-penetrative sex with other women. 
Strong, vivid writers, Dworkin and MacKinnon drew well-deserved attention, even as many readers were unwilling to accept all their ideas. I believe that these brilliant women gave a valuable account of misogynist men's perception of sexual intercourse, but inappropriately broadened their findings into a general account of penetrative intercourse and heterosexuality. The McClary of Feminine Endings does not hold the extreme views of Dworkin and MacKinnon, but there are similarities. Like the radical feminists, McClary seems to question the normative status of a type of sexuality associated with men, in her case the dominating drive toward climax or closure, and she suggests that male-centered and misogynist views of sex have obscured a range of other sensualities, which she associates with women's experiences. In essays about Janika Vandervelde and Laurie Anderson, McClary praises music that offers "pleasure - a quality of timeless, sustained hovering", and states that this quality, associated with femininity, has had less prestige than "desire for the satisfaction of what is experienced as an intolerable lack", eventually leading to a climax "which is quite clearly to be experienced as a metaphorical ejaculation".4

20 I believe McClary's central goal, in her arguments about musical climax, is to praise the "hovering" sensuality, associated with femininity, that mainstream accounts of classical music neglect. At the same time, her book also seems to criticize the potentially overbearing climax-driven model. I agree with McClary that present-oriented, nonteleological pleasure is very important in music, and that its relative obscurity in music criticism reflects gender-related values. ${ }^{5}$ However, there is more to say about climaxes: specifically, I would like to know, with more detail than McClary provides, how various listeners might relate to powerful musical climaxes.

21 McClary is right, of course, that impressive moments of climax appear in classical compositions that are considered strong and powerful, the "master-pieces", and especially in Romantic music. What is it like to listen to such music?

Imagine someone, a woman perhaps, whose habitual non-musical sensuality is not particularly oriented toward a quest for climaxes, who hears climax-oriented music. According to McClary's account of the contagious qualities of music, this listener will feel herself caught up in an increasing momentum toward a point of crisis. Somehow, she feels identified with experiences that are not congruent with her own spontaneous or customary patterns of arousal and pleasure. This encounter may be thrilling; but it may also be disappointing or alienating, in that it does not acknowledge other, different experiences with which this listener identifies more personally.

Now imagine another listener, a sexually aggressive man perhaps, who hears the same music: he may experience feelings of recognition and satisfaction, as he enjoys the match between the music and the temporal patterning of his goal-oriented sexual experiences. With such experiences in mind, McClary suggests that climax-driven classical music can empower men and efface the subjectivities of women.

These schematic descriptions of experiences are plausible. But one can imagine other plausible scenarios. For instance, a feminist formed in the 1970s, when female orgasm was a much-discussed goal of some activists, might identify pleasurably with a musical climax, feeling it as her own. Indeed, her experiential fusion with the music, if we follow McClary's account of musical identification, may yield a sensuous experience that compares favorably with the vicissitudes of sexual intercourse. It would be, at once, an experience of union with something originating outside herself - not, thus, a potentially isolating experience; but at the same time, an experience in which there is no 
problematic gap between the arousal, excitement, and climax of the music and the listener. ${ }^{6}$ In short, people other than sexually aggressive men may identify with, and enjoy, the implicit sexuality of a musical climax.

Another model for a listener's response to musical climax would diverge from McClary's account of musical identification. If one imagines the listener and music as separate beings who interact, and of the listener as a partner of the music, receptive and responsive, one may think of the listener as empathizing with, and enjoying, musical excitement and climax, somewhat as one sexual partner may take pleasure in the excitement and climax of the other. I shall return to this idea in discussing Trevor Hoppe's work.

These scenarios remind us that one should not assess a specific phenomenon, such as a sexual or musical climax, without considering the context that contributes to its meaning. Further, these scenarios are simplistic, in two ways. First, they are close to stereotype in evoking categories of people with uniform, easily described patterns of sensuality; in reality, individuals often have protean, ambiguous sensibilities. And second, I have followed McClary in assuming that sexual and musical sensibilities mirror each other in simple ways - for instance, that one might predict an individual's attitude toward musical climaxes on the basis of their experience of sexual climaxes. But we don't know that such a correlation exists. McClary's eroticized account of listening points toward fascinating issues about musical and sexual experience; to follow up on her work, we need complex, contextual accounts of sexuality, musical experience, and their relationships.

Suzanne Cusick's essay on lesbian musical experience has a different rhetoric from McClary's book. Cusick's explicit orientation is personal and autobiographical, reflecting her own experience, understood as potentially different from experiences of other people (though, by the end of the essay, her speculations develop considerable breadth). She identifies her sexuality as lesbian, but with caution about the determinacy of that label, and asks, in an exploratory manner, what relationships may be found between her sexuality and her musicality. Cusick's framing conception of musical experience is different as well. Unlike McClary, Cusick usually thinks of musical experience in terms of a relationship, as though between two people, rather than an identification created by musical contagion (though, for Cusick, musical experience also has potential for an ecstatic blurring of boundaries).

To understand and specify her experiences, Cusick provides a background of generalizations. She identifies both music and sex as activities where people interact intimately, sharing pleasure in relationships structured by power. Within that general field, she specifies her own preference, both musical and sexual, for relationships where there is no fixed inequality in the distribution of power. She suggests that sexual equality may be especially accessible between women, because both partners have been socialized as "non-power". Her desire for equality in her intense relationships with music, then, may be considered a lesbian quality of her musicality.

Though her rhetoric is autobiographical, Cusick implicitly draws on shared norms that go beyond the purely personal. In particular, her account evokes well-established ethical norms that favor equality, rather than hierarchy, in distribution of power. This gives her presentation an ethical dimension that has attracted many readers. 
30 As the essay develops, Cusick's preference for equality in relationships leads her away from a focus on listening. In a relationship between music and listener, Cusick finds that music tends to be the active partner, the listener receptive; thus, the two do not seem equal in power. Listening, for Cusick, is an intimate experience of pleasure in which the music tends to exercise power over the listener. But if one desires equality in relationships, it seems that listening itself, as a form of receptivity, may be problematic. Thus, in order to describe equality in a quasi-personal relationship with music, Cusick's essay eventually shifts its focus from listening to performance, in which both performer and music may be thought of as active collaborators: "it is an active response - the joining of my body to the music in which 'who's on top' keeps changing - which is truly my preferred response to music".?

31 Thus, a fuller account of listening, along Cusick's lines, would need to interpret the relationship between music and listener, which are perhaps hierarchized and non-equal, and in any case contrasting and complementary. In doing so, one will immediately bump up against conventional conceptions of heterosexual intercourse, which distinguish between active and passive roles, associated with masculinity and femininity; apparently analogous distinctions may be made with regard to non-heterosexual sex (though, as I shall say again later, one must be cautious about assimilating sexual practices that may, from a distance, appear similar). Many conceptions and practices of sex disparage the allegedly passive or feminine role. As Dworkin and MacKinnon show, such negative ideas about passivity are characteristic of misogynist conceptions and experiences of sex; Dworkin and MacKinnon, as well, disparage heterosexual feminine receptivity, regarding the problems of heterosexual intercourse as an incentive to explore different forms of sexuality. In transposing such conceptions to musical relationships, one may also tend to disparage the listener's role as passive.

Cusick's essay gives various ways of thinking about the distinctive role of listeners. She sometimes downplays, or at least qualifies, the apparent power of music over its listeners, stating that she experiences some music as non-coercive, as offering her possibilities of choice. She prefers "musics which invite and allow me to participate or not as I choose, musics with which I experience a continuous circulation of power even when I let the music be 'on top'."8 Another description acknowledges musical activity, while emphasizing the listener's conscious pleasure: "when I encourage students to receive music 'on their backs', paying the closest of attention to what in the music gives them pleasure, I am conscious of doing so to allow the music her own voice (and to allow the students theirs), her own wholeness of utterance, before analytical or cultural-historical interrogation". 9

Cusick refuses to regard music and listener simply as active and passive, and offers subtler alternative conceptions. I want to follow up on Cusick's delicate sexualized consideration of listening, asking what sexual models may exist for the listener's position. Lesbian femmes, gay bottoms, practitioners of sado-masochism, and heterosexual women have found value in sexual roles often disparaged as passive or submissive, despite wellestablished negative stereotypes. Not surprisingly, writers from these perspectives often place their ideas in explicit contrast to the problematic simplifications of Dworkin and MacKinnon. Such work suggests, not only that it may be possible to give positive accounts of receptive music listening, in the context of erotic qualities of music, but also that such accounts may be diverse, reflecting the different subjectivities of listeners. 

themselves as HIV-negative bottoms, explores structures of power and pleasure that define the bottom's role. ${ }^{11}$ These structures, he explains, do not limit the experiential possibilities for individual subjects, but recur as well-established paradigms, accepted by some subjects and used as a reference point for self-understanding by others. Hoppe sets aside any association of bottom position and femininity, in order to interpret without turning immediately to gender norms. The concept of the bottom as, specifically, the receptive partner in anal intercourse is more central to Hoppe's analysis, though he notes that one interview subject rejects this as well. In a recurring conception, the bottom is the partner who takes pleasure in the other partner's, the top's, pleasure. As one man put it, "the bottom is the person who feels pleasure by giving pleasure. And I think the top feels pleasure by feeling pleasure". ${ }^{12}$ Another man says, "I'm talking about just a drive for pleasing a man". He continues, intriguingly: "What I'm thinking of isn't what it would feel like. I'm thinking what it would be like. You know, the whole experience, not just the sensation". ${ }^{13}$ Hoppe summarizes this as a contrast between "an eroticized 'psychological' level" and "the mere embodied sensations of nerve endings". ${ }^{14}$ Some men take the power difference further, saying that they want to submit to another man, or to be used by a top who has no concern for the bottom's pleasure. Others try to describe, in complex ways, a sense that they, as bottoms, also occupy a powerful role. ${ }^{15}$

Where would these ideas take us, as models for listening experience? One analogy would suggest that listeners take pleasure by causing the music to feel pleasure, and then perceiving that pleasure - or more broadly, listeners find pleasure in the intense feelings and activities of the music itself, feelings and activities that the listeners somehow cause. (Perhaps this is a good moment for a reminder that the musical experiences under discussion are constituted by fantasy; "the music" in these scenarios is the music as imagined by the listener. ${ }^{16}$ ) It is as though the music wants or needs me, and responds to my participation, and I take pleasure in its response. Or, somewhat differently, one could understand the music as absorbed in its own sensations, or feelings and activities, while the listener is caught up in the whole situation, sensitively aware of the experiences of both music and listener. One can also draw from Hoppe's material the suggestion that listeners might want to feel themselves being used by music for its own pleasure and excitement, in a relationship where the music has no specific concern for the listener's experience. Such ideas give a context in which one might think of a listener as empathizing with, and enjoying, musical excitement and climax, understood as the experiences of the listener's musical partner.

Can we give experiential vividness to these ideas? Do you imagine, sometimes at least, that the feelings and activities in music that you hear are responses to your presence? That you somehow stir the music, provoking it, causing it to have strong feelings? Can you imagine that you take pleasure in the desire and excitement that you can cause in the music? Or that the music uses you to cause its own pleasure and other strong feelings,

Transposition, 3 | 2013 
without caring much about your experience - and that this whole configuration, nonetheless, is the source of your own pleasure?

I find these questions wonderful and fascinating - even though I am not sure of the answers. I'll say more about that. First, let's continue to another model.

Reflecting on the butch/femme roles that have sometimes structured lesbian relationships, cultural studies scholar Ann Cvetkovich explores the complexities of femme subjectivity. ${ }^{17}$ Not surprisingly (after the work of Sue-Ellen Case and Judith Butler), she questions the relevance of stereotypical heterosexual conceptions of masculine/feminine as well as the active/passive dichotomy. She prefers the term "receptivity" over "passivity", reducing the stigma of the femme's role. Drawing on oral history and autobiographical writing, Cvetkovich finds that many women who value butch/femme roles conceive of the butch as the partner who wants to give pleasure to the femme, though this recurring conception is subject to variations and qualifications. The femme has a strong appetite for pleasure, but also a fear of the vulnerability and loss of control that such pleasure requires. The butch reassures the femme, in part through her recognition and affirmation of the femme's desire. To show the particular power of receptivity, Cvetkovich cites Christine Cassidy's discussion of Walt Whitman as a femme, with an intense appetite to take in experience of the world. Whitman's receptivity becomes the basis of his poetic power..$^{18}$ Cvetkovich quotes Lyndall MacCowan's expression of gratitude for the women who make it possible for her to be a femme: "It was butch women who made it right to give by responding rather than reciprocating, to make love by moving beneath them rather than using my tongue or hands". ${ }^{19}$ And Cvetkovich notes the complex play of "giving" and "taking" in an essay by Joan Nestle: while one might think of the butch as giving, the femme as receiving, things are not so simple. The butch may "take" the femme, but the femme may "take" the butch, for instance into her own body, and may "take" pleasure from the exchange. Both may also be understood as "giving" in various ways. ${ }^{20}$

As models for listening experience, these ideas point to the possibility that music wants to give pleasure to its listeners; that the listener desires musical pleasure but fears its cost in vulnerability or loss of control; that the music can reassure the listener about the listener's musical pleasures; that the listener's desirous receptivity may be continuous with a broader desire for knowledge by experience, by taking in parts of the world, and may yield poetic knowledge. Perhaps the music can "make it right to give by responding rather than reciprocating"; perhaps the "giving and taking" between music and listener can be complex and multiform.

41 To summarize: this brief consideration of the sexual roles of bottom and femme, based on two authors, leads, through analogy, to many possible models of listening experience. An attempt to generalize about musical experience that relies upon dichotomies of active/ passive, or masculine/feminine, appears crude in light of these complex, sensitive accounts of sexual complementarities. The coarse categories of passive and feminine serve only to hide the diversity of a wide range of experiences and relationships, assimilating them by misrepresenting them. This emerges clearly in the pervasive differences between two positions that might both be called "passive" or "feminine" bottom subjectivity, as described by Hoppe, and femme subjectivity, as described by Cvetkovich. ${ }^{21}$ Rather than think about the position of the listener as passive or feminine, perhaps we should ask whether the differences between the positions of bottom and 
femme, as described, or the subtle complexities within each role, point to similar differences, complexities, and subtleties in the possible positions of a musical listener.

Personally, I find all the various musical possibilities that I have derived from Hoppe and Cvetkovich to be fascinating, even alluring; I believe they all point toward insights. I do not find their diversity problematic, because, in general, I believe an important part of musical experience is the indeterminate play, in the imagination of a listener, of various fantasy scenarios that, therefore, need not be unified, nor even logically compatible with one another. This is what I meant before, when I said that I did not know how to answer the questions about listening that arise by analogy from Trevor Hoppe's account of the bottom role. Rather than trying to identify one accurate model of listening, I think it is good to proliferate plausible models. Some of them may appear to contradict others; some and not others may suit particular listeners. That's just fine. Enriching the range of possibilities is a better theoretical goal than reducing them. Further, if a particular image of listening, derived by analogy from non-musical experience, does not seem evocative or useful, there is a gain in understanding from discovering this dissimilarity. The goal of thinking about musical and sexual experiences together is not to prove that they are the same thing, but to explore the resemblances and differences. And matches and mismatches will undoubtedly vary for particular listeners who reflect on these analogies.

Would musical experience, as proposed by the various images I have been exploring, constitute a form of "queer listening"? I am content to accept the idea that listening, when it resembles queer sexuality, is itself queer. ${ }^{22}$ But I have not offered a contrasting model of "straight listening", nor would I know how to develop it. Perhaps music listening is, in general, polymorphous and, in its general lack of conformity to established norms, perverse.

My discussion has followed the cited texts of Mcclary and Cusick in their sharp focus on issues of sexuality. But if music can be sexualized, in various ways, its eroticism coexists with many other qualities. Of course, sensuous charm or quasi-sexual urgency can appear in musical experience along with many other qualities, such as intelligence, sensitivity, wit, sadness, energy, and so on; such varied qualities may appear simultaneously or successively. And questions about agency, anthropomorphism, power, pleasure and so on can take more and less sexual forms. A somewhat exclusive focus on sexuality, in the texts by McClary and Cusick that I have discussed, reflects the moment of their composition: in the early 1990s, it compensated for the relative absence of considerations of sexuality in previous musicology, and gave these texts the vivid polemical flair that ensured their centrality in subsequent discussions. ${ }^{23}$ The present essay gambles on the possibility that such a focus can still yield valuable insights.

Finally, returning to the social setting of the concert, I want to emphasize, again, the discontinuity between the public atmosphere of the classical concert, or the more general communal qualities of classical music, and the inner experiences of listeners. Following McClary, Cusick, and others, I suggested that those experiences have affinities with eroticism, and perhaps with often-stigmatized sexual roles. The classical concert affirms distinctions of public and private, outer and inner, while also, in the constant proximity of community and musical experience, questioning their separation. If a music listener privately enjoys extraordinary intimacy and sensuality, she also experiences, in the real or imagined presence of other listeners, their social containment through codes of decorous behavior and communication. The classical concert experience is unusual in the intensity with which both aspects are present. 


\section{BIBLIOGRAPHY}

CUSICK, Suzanne G., "On a Lesbian Relationship with Music: A Serious Effort Not to Think Straight", in BRETT, Philip, WOOD, Elizabeth and THOMAS, Gary C. (eds.), Queering the Pitch: The New Gay and Lesbian Musicology, second edition, New York, Routledge, 2006, p. 67-83.

CVETKOVICH, Ann, "Recasting Receptivity: Femme Sexualities", in JAY, Karla (ed.), Lesbian Erotics, New York, New York University Press, 1995, p. 125-146.

DWORKIN, Andrea, Intercourse, twentieth anniversary edition, New York, Basic Books, 2006.

ELLIS, Katharine, Music Criticism in Nineteenth-Century France: La Revue et gazette musicale de Paris 1834-80, Cambridge, Cambridge University Press, 1995.

GOEHR, Lydia, The Imaginary Museum of Musical Works: An Essay in the Philosophy of Music, revised edition, Oxford, Oxford University Press, 2007.

HOPPE, Trevor, "Circuits of Power, Circuits of Pleasure: Sexual Scripting in Gay Men's Bottom Narratives", in Sexualities, Vol. 11, № 14, 2011, p. 193-217.

JOHNSON, James H., Listening in Paris: A Cultural History, Berkeley, University of California Press, 1996.

LEPPERT, Richard, The Sight of Sound: Music, Representation, and the History of the Body, Berkeley, University of California Press, 1995.

MAUS, Fred Everett, "The Disciplined Subject of Musical Analysis", in DELL'ANTONIO, Andrew (ed.), Beyond Structural Listening: Postmodern Modes of Hearing, Berkeley, University of California Press, 2004, p. 13-43.

MAUS, Fred Everett, "Time, Embodiment, and Sexuality in Music Theory", in NEUMEIER, Beate (ed.), Dichotonies: Music and Gender, Heidelberg, Winter Verlag, 2009, p. 61-73.

MacKINNON, Catherine A., Feminism Unmodified: Discourses on Life and Law, Cambridge MA, Harvard University Press, 1988.

McCLARY, Susan, Feminine Endings: Music, Gender, and Sexuality, reissue with new introduction, Minneapolis, University of Minnesota Press, 2002.

SEGAL, Lynne, Straight Sex: Rethinking the Politics of Pleasure, Berkeley, University of California Press, 1994.

STERNE, Jonathan, The Audible Past: Cultural Origins of Sound Reproduction, Durham NC, Duke University Press, 2003.

WALTON, Kendall L., Mimesis as Make-Believe: On the Foundations of the Representational Arts, Cambridge MA, Harvard University Press, 1990.

WEBER, William, The Great Transformation of Musical Taste: Concert Programming from Haydn to Brahms, Cambridge, Cambridge University Press, 2007. 


\section{NOTES}

2. For current editions of these texts, see McCLARY, Susan, Feminine Endings: Music, Gender, and Sexuality, reissue with new introduction, Minneapolis, University of Minnesota Press, 2002 and CUSICK, Suzanne G., "On a Lesbian Relationship with Music: A Serious Effort Not to Think Straight", in BRETT, Philip, WOOD, Elizabeth and THOMAS, Gary C. (eds.), Queering the Pitch: The New Gay and Lesbian Musicology, second edition, New York, Routledge, 2006, p. 67-83.

3. For excellent encapsulations see DWORKIN, Andrea, Intercourse, twentieth anniversary edition, New York, Basic Books, 2006; and MacKINNON, Catherine A., Feminism Unmodified: Discourses on Life and Law, Cambridge MA, Harvard University Press, 1988.

4. McCLARY, Susan, Feminine Endings: Music, Gender, and Sexuality, reissue with new introduction, Minneapolis, University of Minnesota Press, 2002, p. 125.

5. I wrote about this in MAUS, Fred Everett, "Time, Embodiment, and Sexuality in Music Theory", in NEUMEIER, Beate (ed.), Dichotonies: Music and Gender, Heidelberg, Winter Verlag, 2009, p. 61-73.

6. Writers on sexuality, feminist and otherwise, sometimes say that women's arousal and climax differ significantly from men's. This suggests that musical climaxes in malecomposed music could be, in some way, discrepant from women's experiences of their own sexual climaxes. Such considerations would be in the spirit of McClary's work, though Feminine Endings does not address women's experiences of sexual climax.

7. CUSICK, Suzanne G., art. cit., p. 77.

8. Ibid., p. 76.

9. Ibid.

10. It would be possible to consider these issues by reflecting on heterosexual experiences; but not easier, despite what one might think of as the greater public familiarity of heterosexuality. See, for thoughtful reflections on women's heterosexuality in relation to feminism, SEGAL, Lynne, Straight Sex: Rethinking the Politics of Pleasure, Berkeley, University of California Press, 1994.

11. HOPPE, Trevor, "Circuits of Power, Circuits of Pleasure: Sexual Scripting in Gay Men's Bottom Narratives", in Sexualities, Vol. 11, № 14, 2011, p. 193-217.

12. Ibid., p. 199.

13. Ibid., p. 200.

14. Ibid.

15. As a study of the self-conceptions of bottoms, Hoppe's essay does not assume that tops would describe or experience the contrasting roles in the same ways.

16. WALTON, Kendall L., Mimesis as Make-Believe: On the Foundations of the Representational Arts, Cambridge MA, Harvard University Press, 1990, is a superb account of art in relation to imagination, or what I would call fantasy.

17. See CVETKOVICH, Ann, "Recasting Receptivity: Femme Sexualities", in JAY, Karla (ed.), Lesbian Erotics, New York, New York University Press, 1995, p. 125-146.

18. Ibid., p. 128-129. 
19. Ibid., p. 130.

20. Ibid., p. 139-141.

21. One could almost say that the bottom and femme roles reverse the relationships of agency and pleasure: the bottom takes pleasure from the top's pleasure, whereas the butch takes pleasure from the femme's pleasure. However, the two positions do not display merely a symmetrical reversal, but differ in many respects. Also, it is important to remember that the essays by Hoppe and Cvetkovich are rich in detail, describing variations in the roles they address. I urge anyone who wants to think about this material to turn to the original texts by Hoppe and Cvetkovich, and many other writers on sexuality, rather than relying on my brief summaries.

22. Cusick's essay, and my extrapolations from Hoppe and Cvetkovich, obviously draw on queer sexualities. McClary's account of feminine temporalities is not marked as either heterosexual or lesbian; perhaps it is "queer" in that it contrasts with ideas about male heterosexuality.

23. Such an exclusive focus on sexuality is not characteristic of other texts by these writers, who have had long, abundant careers. More characteristic is a restless unwillingness to stay within the boundaries of their own previous work.

1. Christian Thorau's initial invitation to me specified that the organizers liked my essay "The Disciplined Subject of Musical Analysis" (in DELL'ANTONIO, Andrew (ed.), Beyond Structural Listening: Postmodern Modes of Hearing, Berkeley, University of California Press, 2004, p. 13-43), and accordingly, the present essay is closely related to the concerns of that earlier work.

\section{ABSTRACTS}

The norms of the classical music concert, familiar from the twentieth century onward in European and United States contexts, favor an apparently uniform practice of attentive, silent listening, the audience seated in rows with a uniform visual focus. However, within this appearance of quiet conformity, listeners have diverse, intense experiences. The discontinuity between experience and demeanor reflects powerful cultural oppositions between inner and outer, public and private. The discontinuity is particularly stark in light of the erotic qualities of music, as described in brilliant work by Susan McClary (Feminine Endings, 1991) and Suzanne Cusick ("On a Lesbian Relationship with Music", 1994). My essay returns to their work, expanding their accounts to consider a broader range of sexual subjectivities, including "bottom" subjectivity as described by Trevor Hoppe and "femme" subjectivity as described by Ann cvetkovich.

Les normes du concert de musique classique, telles qu'elles sont fixées dans les contextes européen et étasunien depuis le début du $\mathrm{XX}^{\mathrm{e}}$ siècle, prescrivent une attitude d'écoute attentive et silencieuse, apparemment uniforme, l'auditoire étant disposé en rangs et les regards des spectateurs orientés tous dans la même direction. Cependant, sous ces apparences de conformité tranquille, les auditeurs vivent des expériences diverses et intenses. La discontinuité qui existe entre l'expérience et le comportement reflète les puissantes oppositions entre l'intérieur et 
l'extérieur, le public et le privé qui caractérisent cette culture. Cette discontinuité apparaît comme particulièrement forte quand on considère les propriétés érotiques de la musique, telles que les décrivent brillamment Susan McClary (dans son ouvrage Feminine Endings en 1991) et Suzanne Cusick (dans son article : «On a Lesbian Relationship with Music » datant de 1994). Cet article s'appuie sur leur travail et tente de le prolonger par la prise en compte d'un éventail plus large de subjectivités sexuelles, notamment la subjectivité du "passif " telle que l'a décrite Trevor Hoppe, et la subjectivité « fem » conceptualisée par Ann Cvetkovich.

\section{INDEX}

Mots-clés: passif, concert classique, fem, féminisme radical, écoute réceptive, Susan McClary, Suzanne Cusick

Keywords: bottom, classical concert, femme, radical feminism, receptive listening

\section{AUTHOR}

\section{FRED EVERETT MAUS}

Fred E. Maus teaches music at the University of Virginia. His research interests include theory and analysis, gender and sexuality, popular music, aesthetics and dramatic and narrative aspects of instrumental music. 